\title{
PERANCANGAN ALAT PENGGILING IKAN DENGAN PENDEKATAN ERGONOMI UNTUK MENINGKATKAN PRODUKTIVITAS
}

\author{
Saufik Luthfianto \\ Fakultas Teknik, Program Studi Teknik Industri \\ Universitas Pancasakti Tegal \\ Email: saufik34@yahoo.com \\ Zulfah \\ Fakultas Teknik, Program Studi Teknik Industri \\ Universitas Pancasakti Tegal \\ Email: ulfah_sz@yahoo.com \\ Fajar Nurwildani \\ Fakultas Teknik, Program Studi Teknik Industri \\ Universitas Pancasakti Tegal \\ Email: danifajar@yahoo.co.id
}

\begin{abstract}
ABSTRAK
Tujuan penelitian ini adalah untuk merancang mesin giling ikan yang sesuai dengan desain ergonomi, menghasilkan mesin penggiling ikan yang mempunyai produktivitas dengan rancangan kekuatan material alat dan mesin motor serta menghitung kapasitas produksi, BEP dan total biaya hasil prodiksi. Penelitian ini menggunakan metode kuantitatif dengan perancangan ergonomi. Hasil penelitian ini adalah perhitungan anthropometri dapat ditentukan melalui fasilitas kerja operator dengan dimensi kursi dengan tinggi $44 \mathrm{~cm}$ dan meja dengan tinggi $67 \mathrm{~cm}$, lebar $63 \mathrm{~cm}$, panjang $130 \mathrm{~cm}$ yang digunakan operator pada proses penggilingan ikan. Penentuan kualitas motor dapat ditentukan dengan daya motor sebesar 2,83 KW atau $3 \mathrm{Hp}$, diameter puli sebesar $20 \mathrm{~cm}$, sabuk pertama 61 inch, sabuk 2 sebesar 68 inch, dengan bahan poros ST 42, tegangan tarik $420 \mathrm{~N} / \mathrm{mm}^{2}$, bahan elektroda AWS e6013, kekuatan tarik elektroda sebesar 427,21 N/mm², Tebal Pengelasan sebesar $3 \mathrm{~mm}$, lebar pengelasan $40 \mathrm{~mm}$ dan faktor keamanan sebesar $\mathrm{N}=3$. Rancangan alat pengiling ikan dapat memproduksi sebanyak 39.600 gram atau lebih maka sudah berada pada titik impas (BEP) atau sudah mendapat keuntungan. Biaya total yang dibutuhkan untuk membuat 39.600 gram Rp 365.522
\end{abstract}

Kata kunci: penggiling ikan, ergonomi, produktivitas.

\section{ABSTRACT}

The purpose of this study was to design a steamroller fish in accordance with ergonomic design, produce fish grinding machine having a draft force productivity by material and machine tool motors, and calculates the production capacity, BEP and the total cost prodiksi results. This study uses a quantitative method with ergonomic design. The results of this study is the calculation of anthropometric can be specified facility operator working with the dimensions of the seat with a height of $44 \mathrm{~cm}$ and a table with a height of $67 \mathrm{~cm}$, width $63 \mathrm{~cm}$, length $130 \mathrm{~cm}$ used in the milling process fish. Determination of the quality of the motor can be determined by the motor power of $2.83 \mathrm{Kw}$ or $3 \mathrm{Hp}$, pulley diameter of $20 \mathrm{~cm}$, the first 61-inch belt, the belt 2 by 68 inches, with the shaft material ST 42, a tensile stress of 420 $\mathrm{N} / \mathrm{mm} 2$, the electrode material AWS e6013, the electrode tensile strength of $427.21 \mathrm{~N} / \mathrm{mm}^{2}$, welding thickness of $3 \mathrm{~mm}$, a width of $40 \mathrm{~mm}$ and welding safety factor of $N=3$. The design tool grinder fish can produce as much as 39,600 grams or more than it already is at break-even point (BEP) or own benefit. The total cost to make 39,600 gram Rp 365, 522.

Keywords: grinder fish, ergonomic, productivity.

\section{PENDAHULUAN}

Pada survey awal di kelompok pengolahan dan pemasaran ikan sumber samudra sawojajar Kabupaten Brebes diperoleh data bahwa pada kelompok tersebut memerlukan alat bantu penggiling ikan sebagai alat bantu pengolahan ikan. Data tersebut berupa data kelompok pengolah ikan dengan $75 \%$ 
masih aktif dalam pengolahan dan pemasaran hasil olahan ikan sedangkan $25 \%$ kelompok masih bergantung pada hasil tangkapan nelayan sehingga dapat dikatakan bahwa kelompok tersebut mempunyai olahan yang sederhana. Data berikutnya dadalah yang menggunakan alat bantu yaitu sekitar $95 \%$ menggunakan manual. Pemakaian alat bantu yang digunakan oleh kelompok tersebut sangat sederhana dan masih menggunakan tenaga manual untuk proses produksinya, hasil produknya pun tidak sesuai yang diharapkan, dengan presentase cacat sebanyak $40 \%$ dari setiap produksi. Alat bantu penggiling ikan yang lama memiliki banyak kekurangan selama digunakan untuk melakukan pekerjaan, terutama pada hasil proses penggilingan yang kurang lembut, desain alat yang tidak sesuai dengan posisi tubuh pekerja dan alat yang tidak sesuai dengan tekstur ikan yang akan dihasilkan, sehingga tidak mampu menghasilkan produk yang sesuai dengan kualitas yang diinginkan dan pemilihan komponen untuk menghasilkan produk yang baik. Mesin pengiling ikan ini merupakan mesin yang digunakan untuk menghancurkan ikan yang telah kering, untuk dihaluskan menjadi tepung ikan, yang digunakan sebagai bahan dasar campuran makanan ternak, karena kandungan protein pada ikan sangat tinggi. Jadi proses pengiling ikan yaitu dengan memanfaatkan energy mekanik yang dihasilkan dari putaran mesin untuk menggerakkan poros, dan putaran mesin tersebut ditransmisikan dengan menggunakan sabuk-V kemudian putaran tersebut digunakan untuk menggerakkan pisau penghancur agar dapat menghaluskan ikan yang sudah kering menjadi tepung.

\section{METODOLOGI PENELITIAN}

Metode penelitian ini merupakan proses yang terkait satu sama lain secara sistematis dan berkesinambungan. Penelitian ini menggunakan metode kuantitatif perancangan ergonomi dan analisa ekonomi teknik sebagai perhitungan total biaya dan kapasitas produksi yang dihasilkan. Metode penelitian ini dirangkaikan melalui proses yang sistematis dengan menunjukkan bahwa hasil dari tiap tahapan akan menjadi masukan pada tahap berikutnya.

\subsection{Tahap Studi Pendahuluan}

Pada tahap ini duraikan mengenai latar belakang, perumusan masalah, tujuan penelitian dan manfaat, studi pustaka, dan studi lapangan yang dijelaskan pada sub bab berikut ini.

a. Latar Belakang

Observasi yang telah dilakukan di pohlaksar diketahui bahwa masih kurang memperhatikan aspek kualitas produk yang dihasilkan. Produk yang dihasilkan hanya diseleksi dengan melihat output yang dihasilkan, sehingga kualitas belum terukur.

b. Perumusan Masalah

Berdasarkan observasi awal yang telah dilakukan maka perlu adanya perbaikan proses produksi dengan merancang bangun alat penggiling ikan secara atribut dan variabel sehingga menghasilkan produk yang sesuai dengan spesifikasi yang ditentukan pemesan.

c. Tujuan dan Manfaat

Tujuan penelitian ini adalah merancang bangun alat penggiling ikan sehingga dapat menjaga kualitas produk sesuai dengan spesifikasi yang ditentukan pemesan. Manfaat penelitian ini adalah menghasilkan alat bantu penggiling ikan.

d. Studi Pustaka

Studi pustaka dilakukan untuk memperoleh informasi pendukung yang diperlukan dalam penyusunan laporan penelitian, yakni dengan mempelajari literatur yang berkaitan dengan masalah ergonomi.

e. Studi Lapangan

Studi lapangan dilakukan untuk memperoleh informasi yang dibutuhkan untuk perancangan alat penggiling ikan. Informasi ini berupa data kualitatif dan data kuantitatif yang digunakan pada pengolahan data selanjutnya.

\subsection{Tahap Pengumpulan data, dan Pengolahan Data}

Pada tahap ini dilakukan pengumpulan dan pengolahan data yang digunakan untuk perancangan alat penggiling ikan, tinggi dan diameter penggiling ikan yang dijelaskan berikut ini.

\subsubsection{Pengumpulan Data}

1. Data perancangan alat penggiling

Data yang diperlukan untuk merancang mesin penggiling yaitu: data mekanisasi alat, data ukuran 
rangka, data daya motor yang diperlukan, data putaran poros pisau, dan data sambungan las.

2. Data perancangan alat penggiling menggunakan ergonomi

Pada tahap ini dilakukan pengumpulan data dimensi penggiling ikan dan data antropometri yang dibutuhkan untuk perancangan alat. Data dimensi yang digunakan adalah panjang, tinggi dan diameter penggiling ikan. Hasil dari wawancara dengan kelompok di tempat penelitian diketahui bahwa. Sampel diambil dengan pengukuran secara langsung di lapangan. Data antropometri diperlukan untuk merancang tinggi tiang yang digunakan untuk penempatan alat bantu sehingga nyaman ketika alat tersebut digunakan. Data antropometri yang diperlukan yaitu tinggi bahu duduk (tbd), tinggi siku duduk (tsd), dan lebar tangan (lt). Ukuran perancangan tinggi tiang alat ini mengacu pada tinggi siku duduk, sehingga alat ini memiliki ketinggian sejajar dengan siku pekerja. Pada proses finishing diusulkan alat bantu inspeksi penggiling ikan. Alat ini memiliki dua alat inspeksi yaitu batas spesifikasi bawah dan atas. Pengambilan data antropometri untuk perancangan alat penggiling ikan ini diambil dari Laboratorium Analisa Perancangan Kerja dan Ergonomi UPS Tegal sebanyak 40 data dan akan dilakukan penambahan pengumpulan data bila diperlukan.

\subsubsection{Pengolahan Data}

Pada tahap ini dilakukan pembuatan diagram rata-rata dan selang untuk mengetahui apakah produk yang dihasilkan terkendali dan juga dilakukan analisis kemampuan proses untuk tinggi penggiling ikan dan diameter. Panjang tidak dilakukan analisis kemampuan proses karena tidak memiliki batas spesifikasi yang baku. Di samping itu dilakukan pengujian data antropometri. Pengujian data antropometri meliputi uji keseragaman, kecukupan, dan kenormalan data. Setelah data tersebut diuji kemudian dilanjutkan dengan penentuan nilai persentil untuk penentuan ukuran rancangan.

\subsection{Pengujian Data}

Setelah dilakukan pengumpulan data, maka dilakukan uji keseragaman dan uji kecukupan data antropometri.

\subsubsection{Uji Keseragaman Data}

Uji keseragaman data berfungsi untuk memperkecil varian yang ada dengan membuang data ekstrim. Jika ada data yang berada di luar batas kendali atas (BKA) ataupun batas kendali bawah (BKB) maka data tersebut dibuang. Langkah pertama dalam uji keseragaman ini adalah perhitungan mean dan standar deviasi untuk mengetahui batas kendali atas dan bawah. Menurut Barnes (1980) rumus yang digunakan dalam uji ini adalah :

$$
\begin{aligned}
\bar{X} & =\frac{\sum_{i=1}^{n} x_{i}}{n} \\
S D & =\sqrt{\frac{\sum(x-\bar{x})^{2}}{n-1}} \\
\mathrm{BKA} & =\bar{x}+2 S D \\
\mathrm{BKB} & =\bar{x}-2 S D
\end{aligned}
$$

dimana :

$\mathrm{SD} \quad=$ standar deviasi

$x_{i} \quad=$ data ke-i

$\bar{x} \quad=$ mean data

$\mathrm{n} \quad=$ jumlah data

BKA = batas kendali atas

$\mathrm{BKB}=$ batas kendali bawah

Jika ada data yang berada di luar batas kendali atas maupun batas kendali bawah, maka data tersebut harus dieliminasi/dihilangkan. Untuk dapat melihat keseragaman data dapat digunakan peta kendali $\bar{x}$. 


\subsubsection{Uji Kecukupan Data}

Uji kecukupan data berfungsi untuk mengetahui apakah data yang diperoleh sudah mencukupi untuk diolah. Sebelum dilakukan uji kecukupan data terlebih dahulu menentukan derajat kebebasan $\mathrm{s}=0,05$ yang menunjukkan penyimpangan maksimum hasil penelitian. Selain itu juga ditentukan tingkat kepercayaan $95 \%$ dengan $\mathrm{k}=2$ yang menunjukkan besarnya keyakinan pengukur akan ketelitian data antropometri, artinya bahwa rata-rata data hasil pengukuran diperbolehkan menyimpang sebesar 5\% dari rata-rata sebenarnya (Barnes, 1980). Rumus uji kecukupan data adalah sebagai berikut :

$N^{\prime}=\left[k / s \sqrt{\frac{N \sum\left(x_{i}{ }^{2}\right)-\left(\sum x_{i}\right)^{2}}{\sum x_{i}}}\right]^{2}$

dengan :

$\mathrm{k} \quad$ = tingkat kepercayaan

$\mathrm{s} \quad=$ derajat ketelitian

$x_{i} \quad=$ data ke-i

$N=$ jumlah data pengamatan.

$N^{\prime}=$ jumlah data teoritis

Data dianggap telah mencukupi jika memenuhi persyaratan $N^{\prime}<N$, dengan kata lain jumlah data secara teotitis lebih kecil daripada jumlah data pengamatan (Wignjosoebroto, 1995).

\subsubsection{Uji Normalitas}

Untuk mengetahui normalitas suatu distribusi data dapat dilakukan dengan Uji KolmogorovSmirnov. Terlebih dahulu hipotesis pengujiannya yaitu:

$\mathrm{H}_{0}$ : Data berdistribusi secara normal

$\mathrm{H}_{1}$ : Data tidak berdistribusi secara normal

Penentuan uji normalitas dengan melihat nilai signifikansinya yang dibandingkan dengan tingkat ketelitian yang digunakan $(\alpha)$. Disini $\alpha$ yang digunakan adalah 0,05 . Bila nilai signifikansi lebih kecil dari

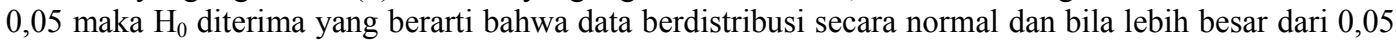
maka $\mathrm{H}_{0}$ ditolak yang berarti bahwa data tidak berdistribusi secara normal.

\subsubsection{Perhitungan Persentil}

Pada penentuan dimensi rancangan alat penggiling ikan dibutuhkan beberapa persamaan berdasarkan pendekatan antropometri, ini berkaitan dengan penentuan penggunaan persentil 5, 50 dan 95 (Panero, 2003). Perhitungan nilai persentil 5, 50 dan 95 dari setiap jenis data yang diperoleh, dilanjutkan dengan perhitungan untuk penentuan ukuran rancangan dan pembuatan rancangan berdasarkan ukuran hasil rancangan. Menurut Sritomo Wignjosoebroto (1995), untuk menghitung persentil 5, 50 dan 95 menggunakan rumus perhitungan yang terdapat pada tabel 2.1 .
a. Persentil $5=\bar{x}-1.645 \sigma_{x}$
b. Persentil $50=\bar{x}$
c. Persentil $95=\bar{x}+1.645 \sigma_{x}$

\subsubsection{Perancangan Produk}

1. Perancangan Mesin Penggiling Ikan

Perancangan produk dimulai dari pengukuran benda kerja, Tahap I. perancangan awal yaitu: mekanisasi alat, perancangan rangka, perancangan daya motor, perancangan poros, perancangan sambungan las, pengujian rantai rol dan spoket, puli yang digunakan, poros, pasak, bantalan, dan mur dan baut. Tahap II. Perancangan. Berdasarkan hasil pengujian bahan dan material akan terbentuk konstruksi. Pengujian Mesin dilakukan serangkaian uji: Tahap I. Pengujian penggunaan mesin mengetahui kenerja mesin. Tahap II. Perancangan Mesin Menganalisa waktu standar, analisa keluhan- keluhan yang terjadi pada mesin.

2. Perancangan Tempat Mesin Penggiling menggunakan Ergonomi

Pada perancangan ergonomic digunakan dari data anthropometri maka akan dihasilkan data yaitu: tinggi bahu duduk (tbd), tinggi siku duduk (tsd), dan lebar tangan (lt). Ukuran perancangan tinggi 
tiang alat ini mengacu pada tinggi siku duduk, sehingga alat ini memiliki ketinggian sejajar dengan siku pekerja.

\subsection{Tahap Pembahasan Hasil Penelitian}

Pada tahap ini dilakukan analisis dan interpretasi hasil terhadap pengumpulan dan pengolahan data sebelumnya.

\subsection{Tahap Kesimpulan dan Saran}

Pada tahap ini akan membahas kesimpulan dari hasi pengolahan data dengan memperhatikan tujuan yang ingin dicapai dari penelitian dan kemudian memberikan saran perbaikan yang mungkin dilakukan untuk penelitian selanjutnya.

\section{HASIL PENELITIAN DAN PEMBAHASAN}

\subsection{Hasil Uji Keseragaman Data}

Tabel 1. Hasil uji keseragaman data

\begin{tabular}{ccccccc}
\hline No. & Deskripsi data & rata-rata & $\boldsymbol{S D}$ & $\boldsymbol{B K} \boldsymbol{A}$ & $\boldsymbol{B K B}$ & Kesimpulan \\
\hline 1 & Tinggi duduk tegak & 85,93 & 1,53 & 88,99 & 82,87 & data seragam \\
2 & Jarak Tangan depan & 67,87 & 1,53 & 70,93 & 64,80 & data seragam \\
3 & Tinggi siku kerja & 11,8 & 1,53 & 14,86 & 8,74 & data seragam \\
4 & Tinggi siku duduk & 20,4 & 1,53 & 23,46 & 17,34 & data seragam \\
5 & Tinggi popliteal & 39,93 & 1,53 & 42,99 & 36,87 & data seragam \\
\hline
\end{tabular}

Dari hasil uji keseragaman data untuk tinggi duduk tegak, jarak tangan depan, tinggi siku kerja, tinggi siku duduk dan tinggi popliteal diperoleh kesimpulan bahwa data diatas seragam karena data sudah berada pada batas-batas pengendalian sehingga tidak perlu membuat peta kendali revisi

\subsection{Hasil Uji Kecukupan Data}

Tabel 2. Hasil uji kecukupan data

\begin{tabular}{cccc}
\hline No. & Deskripsi data & $\boldsymbol{N}^{\prime}$ & Kesimpulan \\
\hline 1 & Tinggi duduk tegak & 0,42 & data cukup \\
2 & Jarak Tangan depan & 0,87 & data cukup \\
3 & Tinggi siku kerja & 3,75 & data cukup \\
4 & Tinggi siku duduk & 6,56 & data cukup \\
5 & Tinggi popliteal & 2,34 & data cukup \\
\hline
\end{tabular}

Dari hasil uji kecukupan data pada tabel 2 untuk tinggi duduk tegak, jarak tangan depan, tinggi siku kerja, tinggi siku duduk dan tinggi popliteal diperoleh kesimpulan bahwa data diatas cukup hal ini karena hasil perhitungan didapatkan nilai N' lebih kecil daripada jumlah pengamatan sebesar $\mathrm{N}$ maka data yang dikeumpulkan telah mencukupi. Pengujian data anthropometri meliputi tinggi tegak duduk (TDT), jangkauan tangan depan (JTD), tinggi siku kerja (TSK), tinggi siku duduk (TSD) dan tinggi plopiteal (TP) diperoleh bahwa data yang diperlukan telah seragam dan cukup, sehingga tidak diperlukan penambahan data tambahan. Selanjutnya parameter data yang meliputi nilai rata-rata dan standar deviasi digunakan untuk perhitungan persentil.

\subsection{Analisis Fasilitas Kerja Pada Operator}

Hasil perhitungan persentil ke-5 dan ke-95 dapat dilihat pada tabel 3 dibawah ini.

Tabel 3. Rekapitulasi hasil perhitungan persentil

\begin{tabular}{clcc}
\hline No. & Deskripsi data & $\boldsymbol{P - 5}$ & $\boldsymbol{P - 9 5}$ \\
\hline 1 & Tinggi duduk tegak & 83,41 & 88,95 \\
2 & Jarak Tangan depan & 65,35 & 70,39 \\
3 & Tinggi siku kerja & 9,28 & 14,32 \\
4 & Tinggi siku duduk & 17,88 & 22,92 \\
5 & Tinggi popliteal & 37,42 & 42,45 \\
\hline
\end{tabular}


Hasil rekapitulasi perhitungan persentil untuk Tinggi Duduk Tegak, Jarak Tangan Depan, Tinggi Siku Kerja, Tinggi Siku Duduk, Dan Tinggi Popliteal menunjukkan bahwa untuk posisi kerja manusia dapat ditentukan dengan persentil 5\% dan persentil 95\%, hasil perhitungan tersebut dapat dilihat pada gambar 1 dibawah ini:

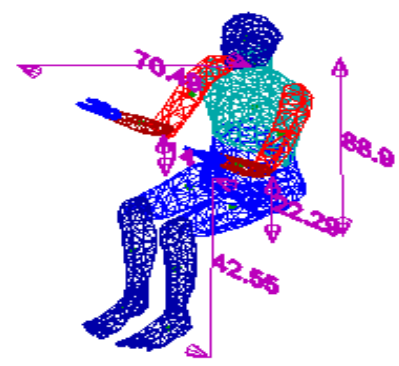

Gambar 1. Posisi kerja duduk

\subsection{Penentuan ukuran meja dan kursi}

Tabel 4. Rekapitulasi penentuan ukuran meja dan kursi

\begin{tabular}{ccc}
\hline Komponen & Dimensi & Ukuran (cm) \\
\hline Meja & Tinggi meja & 67 \\
& Lebar meja & 65 \\
& Panjang Meja & 130 \\
Kursi & Tinggi Kursi & 44 \\
\hline
\end{tabular}

Tinggi meja di dapat dari hasil penjumlahan data antropometri tinggi popliteal persentil ke-95 sebesar 42,45 cm, tinggi siku duduk persentil ke-95 sebesar 22,92. dan toleransi alas kaki sebesar $2 \mathrm{~cm}$ (Nurmianto E, 2004). Hasil dari pengukuran tinggi meja didapatkan $67 \mathrm{~cm}$. Menentukan lebar meja diperlukan data dimensi jangkauan tangan ke depan dengan persentil ke-5, yaitu sebesar $65,35 \mathrm{~cm}$. Penentuan persentil ke-5 untuk jangkauan tangan ke depan bertujuan agar orang-orang yang memiliki jangkauan tangan yang pendek dapat menggunakan rancangan ini tanpa membungkuk untuk mencapai bagian ujung meja. Hasil dari pengukuran lebar meja didapatkan $63 \mathrm{~cm}$. Penentuan panjang meja diperlukan data dimensi dua kali jangkauan tangan ke depan persentil ke-5 sebesar 65,35 cm. Hasil dari pengukuran panjang meja didapatkan $130 \mathrm{~cm}$. Penentuan persentil 5 untuk jangkauan tangan ke depan bertujuan yang memiliki jangkauan tangan pendek dapat menggunakan rancangan ini. Penentuan tinggi kursi memerlukan data dimensi tinggi popliteal persentil ke-95 sebesar 42,45 cm ditambah toleransi alas kaki sebesar $2 \mathrm{~cm}$ (Nurmianto E, 2004). Pemilihan persentil ke-95 untuk tinggi popliteal bertujuan untuk mengakomodasi orang yang mempunyai tungkai bawah yang panjang. Bagi orang yang mempunyai tungkai bawah pendek dapat ditambahkan penyangga pada kaki kursi. Hasil dari pengukuran tinggi kursi didapatkan $44 \mathrm{~cm}$.

\subsection{Penentuan kualitas kekuatan material}

Bahan kayu yang digunakan untuk pembuatan meja menggunakan jenis kayu akasia. Perhitungan tegangan geser pada batang kaki meja yang dibuat sebesar $2,06704.10^{-6} \mathrm{~kg} / \mathrm{mm}^{2}$ dan tegangan geser yang diijinkan pada profil kayu yang digunakan sebesar $0,20625 \mathrm{~kg} / \mathrm{mm}^{2}$, sehingga persyaratan beban diatas meja adalah $\left(2,06704.10^{-6} \mathrm{~kg} / \mathrm{mm}^{2}<0,20625 \mathrm{~kg} / \mathrm{mm}^{2}\right.$, meja cukup kuat untuk menahan beban).

a) Penentuan kualitas mesin motor

Parameter yang dijadikan acuan dalam kualitas motor adalah perhitungan putaran poros motor, berikut adalah hasil dari perhitungan tersebut: 
Tabel 5. Rekapitulasi perhitungan motor

\begin{tabular}{lll}
\hline Komponen & Dimensi & Ukuran \\
\hline Motor & Daya Motor & $2,83 \mathrm{Kw}$ atau 3 Hp \\
Puli & Diameter puli & $20 \mathrm{~cm}$ \\
Sabuk & Sabuk 1 & $61 \mathrm{inch}$ \\
& Sabuk 2 & $68 \mathrm{inch}$ \\
Poros & Bahan poros & $\mathrm{St} 42$ \\
& Tegangan tarik & $420 \mathrm{~N} / \mathrm{mm}^{2}$ \\
Sambungan Las & Bahan elektroda & AWS e6013 \\
& Kekuatan tarik elektroda & $427,21 \mathrm{~N} / \mathrm{mm}^{2}$ \\
& Tebal Pengelasan & $3 \mathrm{~mm}$ \\
& Lebar pengelasan & $40 \mathrm{~mm}$ \\
& Factor keamanan & $\mathrm{N}=3$ \\
\hline
\end{tabular}

Dari perhitungan motor diatas dihasilkan untuk daya motor berukuran $2,83 \mathrm{Kw}$ atau $3 \mathrm{Hp}$ dengan diameter pulli $20 \mathrm{~cm}$, sabuk 161 inch dan sabuk 268 inch, bahan poros st 42 dengan tegangan tarik 420 $\mathrm{N} / \mathrm{mm}^{2}$, sambungan las dengan bahan elektroda AWS e6013, Kekuatan tarik elektroda 427,21 N/mm² Tebal Pengelasan $3 \mathrm{~mm}$, Lebar pengelasan $40 \mathrm{~mm}$, Factor keamanan $\mathrm{N}=3$.

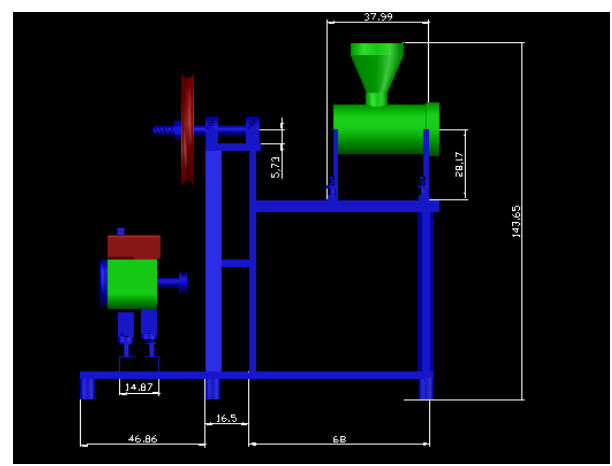

Gambar 3. Rancangan Alat Penggiling Ikan

b) Produktivitas dan biaya

Perhitungan analisa titik impas (BEP) terdiri dari perhitungan alat pengiling ikan dan perhitungan pembuatan alat pengiling ikan, sebagai berikut:

Table 6. Data penggiling ikan

\begin{tabular}{cccccc}
\hline $\begin{array}{c}\text { Investasi } \\
\text { mesin }(\boldsymbol{R} \boldsymbol{p})\end{array}$ & $\begin{array}{c}\text { Tingkat } \\
\text { bunga/periode }\end{array}$ & $\begin{array}{c}\text { Nilai sisa } \\
(\mathbf{R} \boldsymbol{p})\end{array}$ & $\begin{array}{c}\text { Kapasitas alat per } \\
\text { hari }\end{array}$ & $\begin{array}{c}\text { Umur alat } \\
(\text { th })\end{array}$ & $\begin{array}{c}\text { Biaya operator } \\
\text { per hari }(\boldsymbol{R} \boldsymbol{p})\end{array}$ \\
\hline 1.000 .000 & $15 \%$ & 500 & 7.000 gram & 5 tahun & 25.000 \\
\hline
\end{tabular}

Pada table 6 diatas, menjelaskan bahwa investasi alat penggiling ikan adalah Rp. 1.000.000, bunga per tahun $15 \%$, kapasitas alat per hari 7.000 gram, umur alat diperkirakan 5 tahun, dan biaya operator per hari Rp. 25.000

Data tersebut diuraikan dengan menghitung ongkos variabel untuk membuat produk dengan menggunakan persamaan, seperti di bawah ini:

$\mathrm{VC}=$ Rp. $25.000 / 7.000$ gram

$=$ Rp. 3,57/ gram

Hasil perhitungan ongkos variabel pembuatan produk sebesar Rp. 3,57 / gram sedangkan ongkos tetap (fixed cost) untuk biaya penggunaaan alat pengiling ikan, yaitu:

$\mathrm{FC} 1=\mathrm{P}(\mathrm{A} / \mathrm{P}, \mathrm{i} \%, \mathrm{~N})-\mathrm{Rp} 400.000(\mathrm{~A} / \mathrm{F}, \mathrm{i} \%, \mathrm{~N})$

$=\operatorname{Rp} 1.000 .000(\mathrm{~A} / \mathrm{P}, 15 \%, 5)-\operatorname{Rp} 500.000(\mathrm{~A} / \mathrm{F}, 15 \%, 5)$

$=\operatorname{Rp} 1.000 .000(0,2983)-\operatorname{Rp} 500.000(0,1483)$

$=\operatorname{Rp} 298.300-\operatorname{Rp} 74.150$

$=\operatorname{Rp} 224.150$,-

Hasil perhitungan di atas, menjelaskan bahwa besar ongkos tetap (fixed cost) untuk biaya pemotongan menggunakan alat penggiling ikan sebesar Rp 224.150, sehingga total cost (TC) dapat diuraikan, sebagai berikut: 


$$
\begin{aligned}
\mathrm{TC} 1 & =\mathrm{FC}+\mathrm{VC} \\
& =\mathrm{Rp} 224.150,-+\operatorname{Rp} 3,57(\mathrm{X})
\end{aligned}
$$
adalah:

Bila, $\mathrm{p}=\mathrm{Rp} 1.900$ per unit maka jumlah yang harus diproduksi per hari agar mencapai titik impas,

$$
\begin{aligned}
\mathrm{X} & =\mathrm{FC} /(\mathrm{P}-\mathrm{c}) \\
& =\mathrm{Rp} 224.150 /(\mathrm{Rp} 1.900-\mathrm{Rp} .3,57) \\
& =118,19
\end{aligned}
$$

Jadi volume produksi sebesar 118 unit perhari menyebabkan perusahaan berada pada titik impas dan total ongkos yang terjadi, adalah:

$$
\begin{aligned}
\mathrm{TC} & =\mathrm{FC}+\mathrm{cX} \\
& =\operatorname{Rp} 224.150+(\operatorname{Rp} 3,57 \times 39.600) \\
& =\operatorname{Rp} 365.522
\end{aligned}
$$

Jadi apabila rancangan alat pengiling ikan dapat memproduksi sebanyak 39.600 gram atau lebih maka sudah berada pada titik impas (BEP) atau sudah mendapat keuntungan. Biaya total yang dibutuhkan untuk membuat 39.600 gram Rp 365.522. Perhitungan kapasitas alat per tahun bertujuan untuk mengetahui berapa besar kapasitas alat dalam membuat produk yang diproduksi per tahun. Kapasitas perhitungan produksi alat penggiling ikan per bulan. Dari hasil perhitungan didapatkan 56000 gram per hari dan kapasitas per bulan 1.344.000 gram/bulan, biaya penyusutan alat setelah digunakan satu tahun kedepan sebesar Rp 74.000 dengan nilai investasi awal sebesar Rp 1.000 .000 dan untuk nilai sisa alat pengiling ikan pada tahun kelima sebesar Rp 500.000 maka nilai sisa tersebut di estimasikan dapat dijual, apabila rancangan alat pengiling ikan dapat memproduksi sebanyak 39.600 gram atau lebih maka sudah berada pada titik impas (BEP) atau sudah mendapat keuntungan. Biaya total yang dibutuhkan untuk membuat 39.600 gram Rp 365.522.

\section{KESIMPULAN}

Kesimpulan dari penelitian ini adalah:

1. Perhitungan anthropometri dapat ditentukan fasilitas kerja operator dengan dimensi kursi dengan tinggi $44 \mathrm{~cm}$ dan meja dengan tinggi $67 \mathrm{~cm}$, lebar $63 \mathrm{~cm}$, panjang $130 \mathrm{~cm}$ yang digunakan operator pada proses penggilingan ikan yang dirancang.

2. Penentuan kualitas motor dapat ditentukan dengan daya motor sebesar $2,83 \mathrm{Kw}$ atau $3 \mathrm{Hp}$, diameter puli sebesar $20 \mathrm{~cm}$, sabuk pertama 61 inch, sabuk 2 sebesar 68 inch, dengan bahan poros ST 42, tegangan tarik $420 \mathrm{~N} / \mathrm{mm}^{2}$, bahan elektroda AWS 60xx, Kekuatan tarik elektroda sebesar 427,21 $\mathrm{N} / \mathrm{mm}^{2}$, Tebal Pengelasan sebesar $3 \mathrm{~mm}$, lebar pengelasan $40 \mathrm{~mm}$ dan factor keamanan sebesar $\mathrm{N}=3$

3. Rancangan alat pengiling ikan mempunyai produktivitas sebesar 39.600 gram atau lebih maka sudah berada pada titik impas (BEP) atau sudah mendapat keuntungan. Biaya total yang dibutuhkan untuk membuat 39.600 gram Rp 365.522

\section{DAFTAR PUSTAKA}

[1] Anson Charles Charles, Soejono Tjitro dan Stefanus Ongkodjojo, Desain Dan Pembuatan Alat Penggiling Daging Dengan Quality Function Deployment, Jurnal Teknik Industri Vol. 8, No. 2, Desember 2006: 106-113, Jurusan Teknik Mesin, Fakultas Teknologi Industri Universitas Kristen Petra, Surabaya

[2] Bagyo, Sucahyo, 1999. Mekanika Teknik 2, PT Tiga Serangkai Pustaka Mandiri, Surakarta.

[3] Crosby,1979. Statiscal Quality Control, Harper \& Row, New York. Garvin, McCain, 1984. The Game of Science, California: Brooks/Ccole, Montere.

[4] Kamarwan, Sidarta, 1984. Statika dan Bagian Mekanika Teknik, UII Press, Jakarta.

[5] Muddin Saripuddin, A. Haslindah, Jamaluddin, Perancangan Mesin Penggiling Tepung Ikan Pada Nelayan Di Kabupaten Jeneponto, ILTEK,Volume 7, Nomor 13, April 2012 Teknik Mesin Universitas Islam Makassar

[6] Nurmianto, Eko, 2004. Ergonomi Konsep Dasar Dan Aplikasi, Prima Printing, Surabaya. Indonesia, Jakarta.

[7] Wignjosoebroto Sritomo, 2000. Ergonomi, Studi Gerak dan Waktu, Guna Widya, Surabaya. 